\title{
Effects of oxodipine on ${ }^{45} \mathrm{Ca}$ movements and contractile responses in vascular smooth muscle
}

\author{
${ }^{1} \mathrm{~J}$. Tamargo \& T. Tejerina
}

Department of Pharmacology, School of Medicine, Universidad Complutense, 28040 - Madrid, Spain

1 The inhibitory effects of oxodipine, a new dihydropyridine, were compared with those of nifedipine on contractile responses in rat isolated aortic strips and on spontaneous mechanical activity in portal vein segments.

2 In rat isolated aorta oxodipine $\left(\mathrm{IC}_{50}=7.8 \pm 1.8 \times 10^{-9} \mathrm{M}\right)$ and nifedipine $\left(\mathrm{IC}_{50}=8.5 \pm 2.5\right.$ $\left.\times 10^{-9} \mathrm{M}\right)$ dose-dependently inhibited the contractile responses induced by high $\mathrm{K}(80 \mathrm{mM})$, whereas responses to noradrenaline $\left(\mathrm{NA}, 10^{-6} \mathrm{M}\right)$ were only slightly affected $\left(\mathrm{IC}_{50}>10^{-7} \mathrm{M}\right)$. These inhibitory actions were observed with both drugs added either before or after the induced contractions.

3 Contractile responses induced by addition of $\mathrm{Ca}$ to $\mathrm{OCa}$ high-K solution were also dosedependently inhibited by oxodipine $\left(\mathrm{IC}_{50}=4.5 \pm 2.5 \times 10^{-9} \mathrm{M}\right.$ ). However, oxodipine up to $10^{-6} \mathrm{M}$ did not modify the contractile responses obtained in strips incubated in $\mathrm{OCa}$ when $\mathrm{Ca}$ was added in the presence of NA.

4 Oxodipine and nifedipine also inhibited the development of spontaneous mechanical activity in portal vein segments.

5 Oxodipine inhibited ${ }^{45} \mathrm{Ca}$ uptake stimulated by high $\mathrm{K}\left(\mathrm{I}_{50}=8.7 \pm 2.5 \times 10^{-9} \mathrm{M}\right)$ or by NA $\left(\mathrm{I}_{50}>10^{-7} \mathrm{M}\right)$. However, it did not modify ${ }^{45} \mathrm{Ca}$ uptake and ${ }^{45} \mathrm{Ca}$ efflux in resting strips or ${ }^{45} \mathrm{Ca}$ efflux stimulated by NA.

6 These results indicate that the effects of oxodipine on vascular smooth muscle may be due to the blockade of $\mathrm{Ca}$ entry through potential- and receptor-operated channels; it was at least 10 times more selective for potential-operated channels. Oxodipine did not modify $\mathrm{Ca}$ entry through passive leak channels and NA-induced intracellular $\mathrm{Ca}$ release.

\section{Introduction}

It is now well recognized that calcium entry blockers (CEBs) are effective in the prophylaxis and treatment of coronary artery disease, arterial vasospasm and hypertension (Godfraind et al., 1984; Opie, 1984; Epstein et al., 1985) which indicates that vascular smooth muscle is one of the tissues in which these compounds show their characteristic effects. These therapeutic effects of CEBs in vascular smooth muscle fibres have been attributed to inhibition of Ca entry through voltage- and receptor-operated channels (Bolton, 1979; Cauvin et al., 1983; Fleckenstein, 1983; Godfraind et al., 1986). In aortic strips dihydropyridine CEBs exhibit a potent antagonism against depolarization-induced contractile responses (Fleckenstein, 1983; Cauvin et al., 1983), whereas their antagonistic effect against noradrenalineinduced contractions occurs only at high concentrations of these compounds (Schumann et al., 1975;

1 Author for correspondence.
Golenhofen \& Hermstein, 1975; Bolton, 1979). Oxodipine [4-(2,3-methylen-dioxyphenyl)-1,4-dihydro-2, 6 - dimethyl,3 - carboxyethyl - 5 - carboxymethyl - piridine] is a new dihydropyridine derivative (Tejerina et al., 1987) which in contrast to nifedipine is not photolabile. The present study was undertaken to examine the effects of oxodipine on rat isolated aortic strips and portal vein segments and to compare its effects with those of nifedipine, the best known dihydropyridine.

\section{Methods}

\section{Experimental procedure}

Sprague-Dawley rats of either sex $(200-250 \mathrm{~g})$ were killed by a blow on the head. The thoracic aorta and 
the portal vein were dissected and placed immediately in a modified Krebs-Henseleit solution (KS) of the following composition (mM): $\mathrm{NaCl} 118, \mathrm{KCl}$ 4.7, $\mathrm{NaHCO}_{3} 25, \mathrm{MgCl}_{2} 1.2, \mathrm{CaCl}_{2} 1.8$ and glucose 11. The Ca-free KS was prepared by adding $2 \mathrm{~mm}$ EGTA instead of $1.8 \mathrm{mM} \mathrm{CaCl}_{2}$. After excess fat and connective tissue were removed, the aortae were cut into helical strips of about $1.0 \mathrm{~mm}$ width and $20 \mathrm{~mm}$ in length. Aortic strips and vein segments were mounted vertically under $2 \mathrm{~g}$ and $1 \mathrm{~g}$ of tension, respectively, in organ baths containing $10 \mathrm{ml} \mathrm{KS}$. The tissue bath was maintained at $34^{\circ} \mathrm{C}$ and bubbled with $95 \% \mathrm{O}_{2}-5 \% \mathrm{CO}_{2}$ gas mixture. Contractile responses were recorded isometrically by a forcedisplacement transducer (Grass FT03) connected to a Grass polygraph. Each preparation was allowed to equilibrate for at least $2 \mathrm{~h}$ before initiation of experimental procedures and during this period the incubation media were changed every $15 \mathrm{~min}$.

After equilibration the following experiments were performed: (1) In some experiments aortic strips were exposed to single submaximal concentrations of $\mathrm{KCl}(80 \mathrm{~mm})$ and noradrenaline (NA, $\left.10^{-6} \mathrm{M}\right)$. An initial $25 \mathrm{~min}$ control contraction was obtained in each experiment with the appropriate stimulating agent and strips were then rested for a minimum of $45 \mathrm{~min}$. Control contractile responses for each agonist were obtained at the beginning of the experiment until two successive responses were almost identical in height. This was followed by exposure to oxodipine or nifedipine for a $10 \mathrm{~min}$ period in both cases before the addition of $\mathrm{KCl}$ or NA and during the $25 \mathrm{~min}$ re-exposure to the stimulating agents. Only one agonist was used in each experiment. The results of these experiments are expressed as a percentage of the maximal control agonist-induced contractile responses. (2) To determine whether oxodipine and nifedipine could relax an existing contraction, aortic strips were contracted by single submaximal concentrations of NA or $\mathrm{KCl}$. When the contractile response to either agonist was maximum, oxodipine or nifedipine was added in progressively increasing cumulative concentrations $\left(10^{-7} \mathrm{M}-\right.$ $5 \times 10^{-4} \mathrm{M}$ ). Strips were allowed to reach a new steady-state tension before each successive concentration of the relaxant drug. The results were expressed as percentage of the maximal control agonist-induced responses. (3) In additional experiments dose-response curves to $\mathrm{CaCl}_{2}(1-5 \mathrm{~mm})$ were obtained in aortic strips incubated in Ca-free KS containing $2 \mathrm{mM}$ EGTA for $2 \mathrm{~h}$ and then in Ca-free high-K $(80 \mathrm{~mm})$ solution for $10 \mathrm{~min}$ before adding the drugs (Barrigón et al., 1984). The results were expressed as a percentage of the maximal contractile response induced by $5 \mathrm{mM} \mathrm{CaCl}$. (4) To study the effects of oxodipine on a membrane store of $\mathbf{C a}$ mobilized by NA the experimental protocol employed was similar to that previously described by Ebeigbe \& Aloamaka (1985). Strips were stimulated by $10^{-5} \mathrm{M}$ NA. When the contractile response was stable, strips were rinsed with Ca-free $\mathrm{KS}$ for $10 \mathrm{~min}$ ('Ca-washing') followed by $5 \mathrm{~min}$ exposure to $1.6 \mathrm{~mm}$ Ca KS ('Ca-loading') and finally, exposure to $\mathrm{Ca}$ washing $\mathrm{KS}$ for $1 \mathrm{~min}$, followed by $10^{-5} \mathrm{M}$ NA stimulation. The above protocol was repeated in the presence of oxodipine, added $5 \mathrm{~min}$ into the ' $\mathrm{Ca}$ washing' period or $2 \mathrm{~min}$ at the end of the 'Caloading' period. Control tissues incubated with ethanol (i.e. solvent for oxodipine and nifedipine) were always run in parallel in each of these experimental designs, the change in responsiveness of the control strips during the whole time course of these experiments being $6.9 \pm 4.6 \%$.

\section{Measurements of ${ }^{45}$ Ca movements}

Techniques employed to estimate ${ }^{45} \mathrm{Ca}$ movements in aortic strips were as previously described by Godfraind (1983) and Barrigón et al. (1984). To determine ${ }^{45} \mathrm{Ca}$ uptake, aortic strips were bisected and in each experiment half of the aorta served as control and the other half as the experimental strip. Both halves were equilibrated for $1 \mathrm{~h}$ under $1 \mathrm{~g}$ of tension in Tris Buffer solution (TS) of the following composition (mM): $\mathrm{NaCl} 160, \mathrm{KCl} 4.6, \mathrm{CaCl}_{2} 1.8, \mathrm{MgCl}_{2} 1.2$, glucose 11 and tris-hydroxymethyl-amino-methane 6.0. This solution was adjusted to $\mathrm{pH} 7.4$ with $4 \mathrm{~N}$ $\mathrm{HCl}$ and gassed with $100 \% \mathrm{O}_{2}$. After equilibration strips were further incubated for $5 \mathrm{~min}$ in TS containing ${ }^{45} \mathrm{Ca}$ (specific activity $0.4 \mu \mathrm{Cim}^{-1}$; The Radiochemical Centre, Amersham) either in the presence or absence of oxodipine and then for another $5 \mathrm{~min}$ in the same solution with or without the addition of $80 \mathrm{mM} \mathrm{KCl}$ or $10^{-6} \mathrm{M}$ NA. At this time strips were washed in $50 \mathrm{mM} \mathrm{LaCl}$-Ca-free TS for $5 \mathrm{~min}$ to remove extracellular bound $\mathrm{Ca}$. Afterwards strips were removed, blotted and weighted. The strips were then placed in scintillation vials and $0.5 \mathrm{ml}$ of Soluene-100 (Packard) added and the strips digested overnight at $50^{\circ} \mathrm{C}$. Radioactivity was assayed in a liquid scintillation counter (Intertechnique Model SL-3000) as previously described (Barrigón et al., 1983; 1984).

To study ${ }^{45} \mathrm{Ca}$ efflux in non-stimulated aortic strips, preparations were labelled with ${ }^{45} \mathrm{Ca}$ TS (sp. act. $2 \mu \mathrm{Ci} \mathrm{ml}^{-1}$ ) for $2 \mathrm{~h}$ and then placed in successive tubes containing $2 \mathrm{ml}$ of Ca-free TS every min for the 30 min duration of the washout. In some vials oxodipine was added to the $\mathrm{Ca}$-free TS. The radioactivity lost into the tubes and present at the end of the experiment was measured as described by Barrigón et al. (1984). The data obtained were plotted as desaturation curves which illustrate the decline of 
tissue ${ }^{45} \mathrm{Ca}$ with time. ${ }^{45} \mathrm{Ca}$ efflux stimulated by NA $\left(10^{-5} \mathrm{M}\right)$ was studied following the technique previously described by Godfraind (1983). Aortic strips were preincubated for $2 \mathrm{~h}$ in ${ }^{45} \mathrm{Ca}$ containing $\mathrm{KS}$ $\left(2 \mu \mathrm{Ci} \mathrm{ml}^{-1}\right)$, oxodipine being added or not during the last $20 \mathrm{~min}$. The strips were then transferred to non-radioactive KS also with or without oxodipine and $5 \mathrm{~min}$ later to the same solution containing or not containing NA $\left(10^{-6} \mathrm{M}\right)$. Afterwards strips were treated as for ${ }^{45} \mathrm{Ca}$ uptake experiments.

\section{Drugs}

The following drugs were used: oxodipine (IQB, S.A.), nifedipine (Bayer) and noradrenaline bitartrate (Sigma). Oxodipine and nifedipine were initially dissolved in $99 \%$ ethanol and further dilutions were made in KS, but control experiments demonstrated that the highest ethanol level used at $10^{-6} \mathrm{M}$ have no effect on vascular smooth muscle contraction. Values were expressed as the mean \pm s.e.mean and statistical analysis was performed by use of Student's $t$ test. The differences between control and experimental values were considered significant when $P<0.05$. Dose-response slopes were analysed to give the concentration of oxodipine or nifedipine producing a $50 \%$ inhibition of the maximal contractile response $\left(\mathrm{IC}_{50}\right)$ or of the maximal NA and high-K dependent ${ }^{45} \mathrm{Ca}$ uptake $\left(\mathrm{I}_{50}\right)$ using a linear regression analysis (method of least squares).

\section{Results}

Effects on resting and spontaneous mechanical activity

The effects of oxodipine and nifedipine were studied on changes in base-line tension and spontaneous mechanical activity in aortic strips and portal veins, respectively. Both drugs had no effect on resting tension but inhibited in a dose-dependent manner the rate and amplitude of spontaneous myogenic activity in portal veins. The $\mathbf{I C}_{50}$ values for oxodipine and nifedipine inhibition of the amplitude of spontaneous activity were $2.5 \pm 1.2 \times 10^{-8} \mathrm{M}$ and $7.0 \pm 0.5 \times 10^{-8} \mathrm{M}$, respectively, this difference being statistically significant $(P<0.05)$.

\section{Effect on contractions induced by $\mathrm{KCl}$ and $\mathrm{NA}$}

The inhibitory effect of oxodipine and nifedipine on contractile responses induced by $\mathrm{KCl}(80 \mathrm{~mm})$ and
NA $\left(10^{-6} \mathrm{M}\right)$ were quantified and compared in isolated aortic strips. Both agonists produced equipotent submaximal contractile responses, $642.8 \pm 36.0$ $\mathrm{mg}$ and $842.0 \pm 88.9 \mathrm{mg}$, respectively $(n=8$; $P>0.05$ ), whereas maximal contractile responses were obtained with $100 \mathrm{mM} \mathrm{KCl}(700.2 \pm 28.5 \mathrm{mg}$, $n=8)$ and $10^{-5} \mathrm{M}$ NA $(940.8 \pm 32.9 \mathrm{mg}, n=8)$. The effects of oxodipine, $10^{-9} \mathrm{M}-10^{-7} \mathrm{M}$, on the time courses of the $\mathrm{KCl}$ - and NA-induced contractions are shown in Figure 1. Oxodipine produced a dosedependent inhibition of the contractile response induced by both stimulating agents. However, whereas $10^{-7} \mathrm{M}$ oxodipine almost suppressed the contractile response induced by $\mathrm{KCl}$, this concentration left unaltered about $50 \%$ of the response induced by NA. The $\mathrm{IC}_{50}$ values for oxodipine and

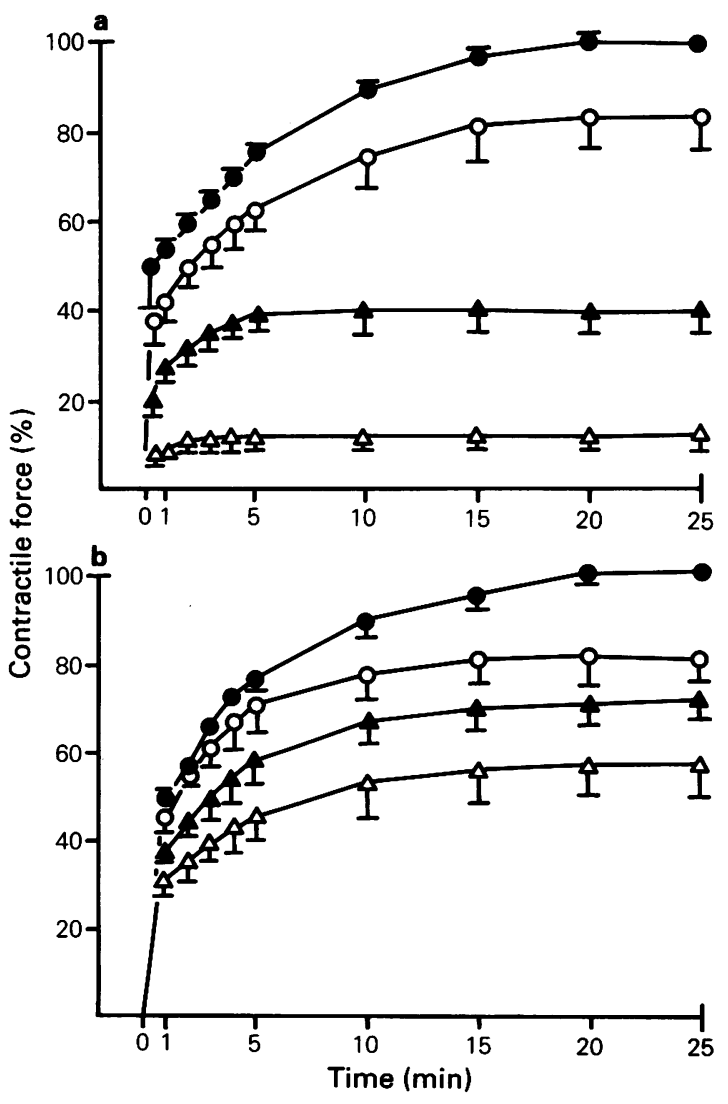

Figure 1 Time course of the contractions induced by (a) high $\mathrm{K}(80 \mathrm{mM})$ and (b) noradrenaline $\left(10^{-5} \mathrm{M}\right)$ in rat aortae pretreated or not with oxodipine. Each point represents the mean of 8 experiments; vertical lines indicate s.e.mean. (O) Controls; $(O)$ after oxodipine, $10^{-9} \mathrm{M},(\Delta) 10^{-8} \mathrm{M}$ and $(\Delta) 10^{-7} \mathrm{M}$. 


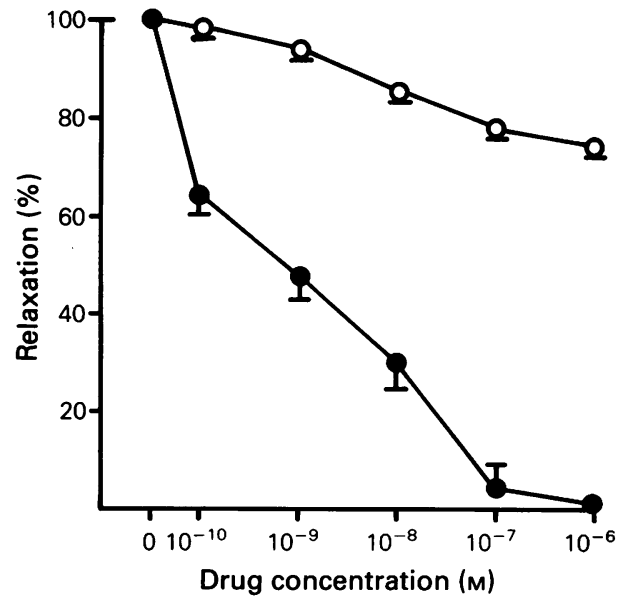

Figure 2 Relaxation of high-K- $(0,80 \mathrm{~mm})$ and noradrenaline-induced $\left(\mathrm{O}, 10^{-5} \mathrm{M}\right)$ contractions by oxodipine. Ordinate scale: relaxation (\% of control values). Each point represents the mean of 8 experiments; vertical lines indicate s.e.mean.

nifedipine-induced depression of high-K-induced responses were $7.8 \pm 1.8 \times 10^{-9} \mathrm{M}$ and $8.5 \pm 2.5 \times$ $10^{-9} \mathrm{M}(P>0.05)$, respectively, which indicates that both drugs are almost equipotent on the contractile responses induced by $80 \mathrm{mM} \mathrm{KCl}$.

Figure 2 shows the relaxant effect of cumulatively increasing concentrations of oxodipine on aortic strips previously contracted with either $80 \mathrm{mM} \mathrm{KCl}$ or $10^{-6} \mathrm{M}$ NA. Cumulative increases in the concentration of oxodipine and nifedipine $\left(10^{-10} \mathrm{M}-10^{-6} \mathrm{M}\right)$ to strips previously contracted with $\mathrm{KCl}$ resulted in a dose-dependent relaxation with an $\mathrm{IC}_{50}$ of $3.0 \pm 2.1 \times 10^{-9} \mathrm{M}$ and $7.5 \pm 2.1 \times 10^{-9} \mathrm{M}$, respectively $(P>0.05)$. Conversely, at the highest concentration tested $\left(10^{-6} \mathrm{M}\right)$ oxodipine and nifedipine relaxed strips previously contracted with NA by only $15.3 \pm 3.2 \%$ and $26.1 \pm 1.8 \%$ of its maximum, respectively.

\section{Effects on Ca-induced contractions}

The inhibitory effects of oxodipine on the $[\mathrm{Ca}]_{0}$-dependent contractile responses are shown in Figure 3. Following incubation for $2 \mathrm{~h}$ in a Ca-free high-K $(80 \mathrm{~mm}) \mathrm{KS}$, the addition of $\mathrm{Ca}$ to the bathing media (1-5 mM) caused a contraction of the aortic strips in a dose-dependent manner. The maximum contractile response induced by $5 \mathrm{mM}$ $\mathrm{CaCl}_{2}$ was similar to that induced by $10^{-6} \mathrm{M} \mathrm{NA}$ $(1001.2 \pm 83.4 \mathrm{mg}$ as compared to $842.0 \pm 88.9 \mathrm{mg}$,

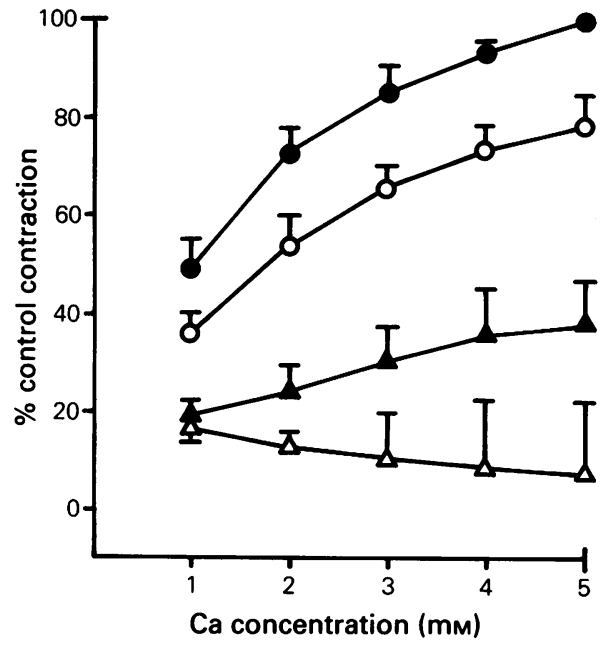

Figure 3 Effects of oxodipine on the restoration of the isometric contractions of aortic strips by addition of calcium (1-5 mM) to Ca-free high-K (80 mM) medium. Ordinate scale: percentage of the maximum control contractions obtained with the highest concentration of calcium in each experiment. Each point represents the mean of 6 experiments; vertical lines indicate s.e.mean. (O) Controls; (O) after oxodipine $10^{-10} \mathrm{M},(\Delta) 10^{-9} \mathrm{M}$ and $(\Delta) 10^{-8} \mathrm{M}$.

$n=8, P>0.05$ ). Oxodipine, $10^{-10} \mathrm{M}-10^{-8} \mathrm{M}$, not only produced a progressive decrease in the amplitude of Ca-induced contractions of $\mathrm{K}$-depolarized aortic strips but also caused a progressive shift of $\mathrm{Ca}$ concentration-response curves downward and to the right. Regression analysis of the inhibition yielded an IC $_{50}$ of $4.5 \pm 2.5 \times 10^{-9} \mathrm{M}$.

In another group of experiments the effects of oxodipine were studied on the contractile responses induced by NA in strips which were incubated for $10 \mathrm{~min}$ in Ca-free $\mathrm{KS}$, then in 'Ca-loading' $\mathrm{KS}$ for $5 \mathrm{~min}$ and finally in Ca-free $\mathrm{KS}$ for $1 \mathrm{~min}$. At this time stimulation with NA $\left(10^{-5} \mathrm{M}\right)$ resulted in a phasic contraction of an amplitude of $729.0 \pm 72.9 \mathrm{mg}(n=6)$, presumed to reflect $\mathrm{Ca}$ mobilization from a membrane-bound store (Karaki et al., 1979). In 6 experiments oxodipine, $10^{-6} \mathrm{M}$, had no effect on the magnitude of the NA-induced phasic contraction when applied before 'Ca-loading' $(619.7 \pm 71.5 \mathrm{mg}, P>0.05)$ or during 'Ca-loading' (625.0 $\pm 50.2 \mathrm{mg}, P>0.05$ ).

\section{Effects on ${ }^{45} \mathrm{Ca}$ uptake and ${ }^{45} \mathrm{Ca}$ efflux}

The effects of oxodipine, $10^{-8} \mathrm{M}-10^{-6} \mathrm{M}$, were studied on the $\mathrm{La}^{3+}$-resistant ${ }^{45} \mathrm{Ca}$ uptake in resting, 
Table 1 Effect of oxodipine on lanthanum-resistant ${ }^{45} \mathrm{Ca}$ uptake in resting aortae and in aortae stimulated with $80 \mathrm{mM} \mathrm{KCl}$ or $10^{-6} \mathrm{M}$ noradrenaline

$\begin{array}{lccc}\begin{array}{l}\text { Drug } \\ \text { Concentration } \\ (M)\end{array} & \begin{array}{c}\text { Unstimulated } \\ \text { (controls) }\end{array} & K C l & \begin{array}{c}{ }^{45} \text { uptake }\left(\mu \mathrm{mol} \mathrm{kg}^{-1} \text { wet wt. }\right) \\ \text { Stimulated }\end{array} \\ & & & \text { Noradrenaline } \\ 0 & 86.0 \pm 6.8 & 317.0 \pm 11.0 & 215.2 \pm 10.2 \\ 10^{-10} & & 299.1 \pm 12.3 & 203.1 \pm 14.3 \\ 10^{-9} & & 281.2 \pm 12.8^{*} & 190.6 \pm 10.7 \\ 10^{-8} & 85.2 \pm 5.8 & 203.5 \pm 10.0^{* * *} & 170.6 \pm 12.5^{* *} \\ 10^{7} & 88.6 \pm 6.9 & 110.4 \pm 10.5^{* * *} & 148.5 \pm 10.5^{* * *}\end{array}$

Results shown are means \pm s.e.mean, $n=9$

${ }^{*} P<0.05,{ }^{* *} P<0.01,{ }^{* * *} P<0.001$.

non-stimulated, as well as in aortic strips stimulated by $80 \mathrm{mM} \mathrm{KCl}$ and $10^{-5} \mathrm{M}$ NA. Oxodipine, $10^{-7} \mathrm{M}$, had no significant effects on ${ }^{45} \mathrm{Ca}$ uptake in resting, non-stimulated aortic strips $(86.0 \pm 6.8$ as compared to $88.6 \pm 6.9$ umol kg $\mathrm{kg}^{-1}$ aorta; $n=6, P>0.05$ ), but produced (Table 1) a significant dose-dependent inhibition of ${ }^{45} \mathrm{Ca}$ uptake stimulated by $\mathrm{KCl}(80 \mathrm{mM})$ and NA $\left(10^{-6} \mathrm{M}\right)$. In order to analyse the dosedependency of the inhibitory effects of oxodipine on high-K and NA-induced ${ }^{45} \mathrm{Ca}$ uptake the procedure of Meisheri et al. (1981) was used. ${ }^{45} \mathrm{Ca}$ uptake was measured in unstimulated strips and from these, averaged values for the increase in $\mathrm{Ca}$ uptake over control by the stimulating agent, in the absence as well as the presence of oxodipine were calculated. \% inhibitions of ${ }^{45} \mathrm{Ca}$ uptake by oxodipine were then obtained to produce Figure 4. Oxodipine, $10^{-10} \mathrm{M}-$ $10^{-7} \mathrm{M}$ dose-dependently inhibited ${ }^{45} \mathrm{Ca}$ uptake stimulated by $80 \mathrm{~mm} \mathrm{KCl}$ (Figure 4a). Concentration-inhibition curves for contraction and ${ }^{45} \mathrm{Ca}$ uptake were almost superimposed and thus $\mathrm{IC}_{50}$ and $\mathrm{I}_{50}$ values were similar $\left(7.8 \pm 1.8 \times 10^{-9} \mathrm{M}\right.$ and $8.7 \pm 2.5 \times 10^{-9} \mathrm{M}$, respectively). Oxodipine also decreased ${ }^{45} \mathrm{Ca}$ uptake in strips stimulated by $10^{-5} \mathrm{M}$ NA. As is shown in Figure $4 \mathrm{~b}$, concentrationinhibition curves for contraction and ${ }^{45} \mathrm{Ca}$ uptake were also superimposed $\left(\mathrm{IC}_{50}\right.$ and $\mathrm{I}_{50} \geqslant 10^{-7} \mathrm{M}$, respectively). These results seem to indicate that even when oxodipine-induced inhibition of high $\mathrm{K}$ - and NA-induced contractions can be related to the blockade of $\mathrm{Ca}$ entry induced by both agonists, ${ }^{45} \mathrm{Ca}$ uptake stimulated by NA was more resistant to oxodipine inhibition than high $\mathrm{K}$-stimulated ${ }^{45} \mathrm{Ca}$ uptake.

The effects of oxodipine were also studied on ${ }^{45} \mathrm{Ca}$ efflux in non-stimulated as well as in aortic strips stimulated by $10^{-5} \mathrm{M}$ NA. In non-stimulated strips and following exposure for $2 \mathrm{~h}$ to ${ }^{45} \mathrm{Ca}$-labelled TS the strips were rinsed with Ca-free-TS for the first $18 \mathrm{~min}$ of the $30 \mathrm{~min}$ washout and with Ca-free-TS containing $10^{-6} \mathrm{M}$ oxodipine for the final $12 \mathrm{~min}$. The desaturation curves show (Figure 5) that oxodipine had no effect on the percentage of ${ }^{45} \mathrm{Ca}$ remaining in the aorta.

Furthermore, even at the highest concentration tested, $10^{-6} \mathrm{M}$, oxodipine had no effect on the tissue content of ${ }^{45} \mathrm{Ca}$ after $2 \mathrm{~h}$ incubation in ${ }^{45} \mathrm{Ca}$ containing solution $\left(0.975 \pm 0.11 \mathrm{mmol} \mathrm{kg}^{-1}\right.$ wet wt.) as compared to the values obtained in control tissues $\left(0.980 \pm 0.09 \mathrm{mmol} \mathrm{kg}^{-1}\right.$ wet wt.; $\left.\quad n=8, \quad P>0.05\right)$. When $10^{-5} \mathrm{M}$ NA was added for $2 \mathrm{~min}$, a significant decrease $(P<0.05)$ of similar magnitude in residual ${ }^{45} \mathrm{Ca}$ content was observed both in control $\left(0.685 \pm 0.06 \mathrm{mmol} \mathrm{kg}^{-1}\right.$ wet wt. $)$ and oxodipinepretreated strips $\left(0.711 \pm 0.08 \mathrm{mmol} \mathrm{kg}^{-1}\right.$ wet wt.; $n=8, P>0.05$ ). These results indicate that oxodipine does not modify NA-stimulated ${ }^{45} \mathrm{Ca}$ efflux.

\section{Discussion}

The results of this paper demonstrate that oxodipine, a new dihydropyridine derivative, exhibits on rat isolated aortic strips and portal vein segments effects similar to those previously described with nifedipine (Godfraind, 1983) and other dihydropyridines (Godfraind, 1981; Cauvin et al., 1983; Fleckenstein, 1983). Thus, the mechanism through which oxodipine relaxes vascular smooth muscle fibres seems to be related to its ability to inhibit the influx of extracellular $\mathrm{Ca}$ through potential- (POCs) and receptoroperated channels (ROCs) of the cell membrane.

Different experimental results demonstrated that oxodipine inhibited $\mathrm{Ca}$ entry through POCs: (1) oxodipine inhibited in a dose-dependent manner the contractile responses induced by $\mathbf{K}$ depolarization or by increases of extracellular $\mathrm{Ca}$ in $\mathrm{K}$-depolarized aortic strips. These responses are entirely dependent 


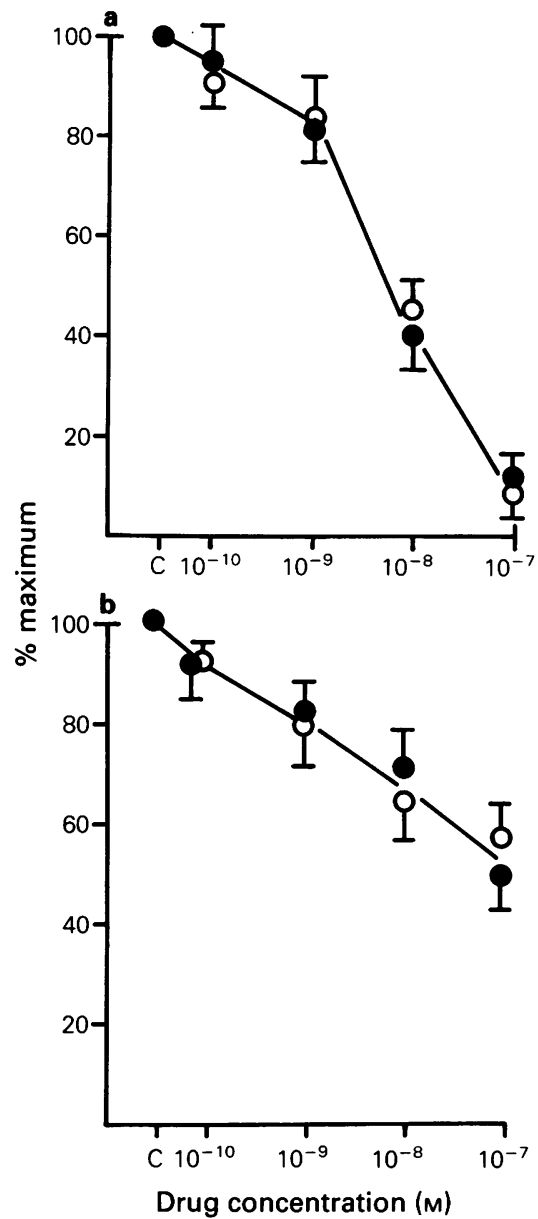

Figure 4 Inhibitory effect of oxodipine on (a) high $\mathrm{K}$ $(80 \mathrm{mM})$ and (b) noradrenaline-induced $\left(10^{-6} \mathrm{M}\right){ }^{45} \mathrm{Ca}$ uptake $(O)$ and contractile force $(O)$ in rat isolated aortae. Ordinate scales: oxodipine-sensitive component as $\%$ of the maximum. Each point represents the mean of at least 6 experiments; vertical lines indicate s.e.mean.

upon the influx of extracellular Ca through POCs (Hudgins \& Weiss, 1968; Godfraind \& Kaba, 1969) and have been used to provide a simple means of studying drugs with possible $\mathrm{Ca}$ entry blocking properties (Haeusler, 1972; Godfraind, 1981). (2) Oxodipine was more potent than nifedipine at inhibiting the spontaneous myogenic activity in rat portal veins. This myogenic activity is also dependent on extracellular Ca (Sigurdson et al., 1975) and has been related to $\mathrm{Ca}$ entry through POCs (Golenhofen \& Lammel, 1972). (3) At the same range

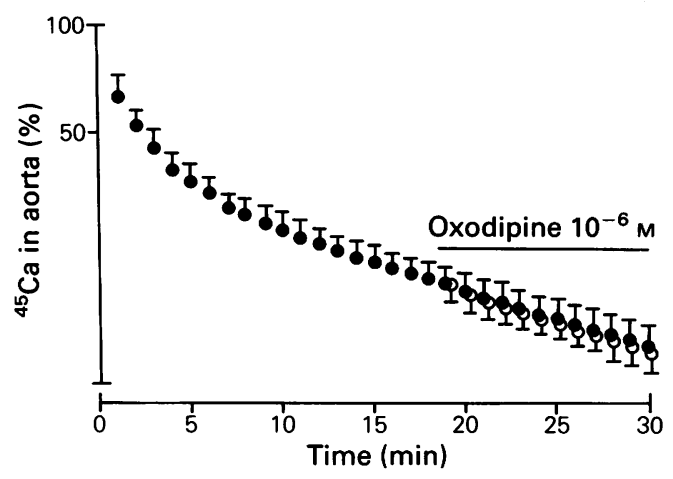

Figure 5 Effect of oxodipine, $10^{-6} \mathrm{M}$, on ${ }^{45} \mathrm{Ca}$ efflux from rat isolated aortic strips. Muscles were incubated for $2 \mathrm{~h}$ in ${ }^{45} \mathrm{Ca}$ before washout in $\mathrm{Ca}$-free solution. Each point represents the mean of 6 experiments. (O) Controls. (O) Oxodipine-treated strips (17 to $30 \mathrm{~min}$ ).

of concentrations at which it inhibited $\mathrm{K}$-induced contractions, oxodipine also inhibited dosedependently the ${ }^{45} \mathrm{Ca}$ uptake stimulated by high $\mathrm{K}$ without altering resting ${ }^{45} \mathrm{Ca}$ uptake. Moreover, concentration-inhibition curves for $\mathrm{K}$-induced contractions and ${ }^{45} \mathrm{Ca}$ uptake were almost superimposed. This indicates that an inhibition of $\mathrm{Ca}$ entry through POCs was responsible for the inhibitory effect of oxodipine on contractile responses induced by high $\mathrm{K}$ and $\mathrm{Ca}$ in aortic strips, as well as for the suppression of the myogenic activity in rat portal veins. However, as has been previously described with other CEBs (Cauvin et al., 1983; Godfraind, 1983; Godfraind et al., 1986), even at high concentrations oxodipine had no affect on ${ }^{45} \mathrm{Ca}$ uptake in resting aortic strips. This suggests that $\mathrm{Ca}$ entry through passive membrane leak channels is insensitive to oxodipine.

Furthermore, most of the CEBs are relatively more potent at inhibiting $\mathrm{K}$-induced contractions than NA-induced contractions (Godfraind, 1981; Cauvin et al., 1983; Kazda et al., 1983) and this is also true for oxodipine. In fact, oxodipine inhibited NA-induced contractions at concentrations about three orders of magnitude higher than those required to inhibit Ca-induced contractions in K-depolarized aortic strips. NA-induced contractions can be resolved into two components, an initial phasic component which is due to the release of $\mathrm{Ca}$ from intracellular stores (Hudgins \& Weiss, 1968; Godfraind \& Kaba, 1969) and a tonic component which is associated with an increase in $\mathrm{Ca}$ influx through ROCs (Hudgins \& Weiss, 1968; Deth \& Van Breemen, 1974). In the present experiments the inhibitory effect of oxodipine on total contractile 
responses to NA paralleled its attenuation of the tonic component. In fact, oxodipine-sensitive ${ }^{45} \mathrm{Ca}$ influx and contractions showed a similar concentration-response relationship, suggesting that oxodipine-induced inhibition of NA contractions can be related to the blockade of $\mathrm{Ca}$ entry through ROCs. However, if at the high concentrations used NA depolarized the membrane potential of vascular smooth muscle fibres, the inhibitory effect of oxodipine on NA-induced contractions could be attributed to inhibition of $\mathrm{Ca}$ entry through both POCs and ROCs. Furthermore, when these results are compared with those obtained in aortic strips stimulated by high $\mathrm{K}$, it is evident that oxodipine was at least two orders of magnitude more selective at inhibiting $\mathrm{Ca}$ entry through POCs than through ROCs. These results confirm recent data in rat cultured aortic smooth muscle cells (Ruegg et al., 1988) demonstrating that ${ }^{45} \mathrm{Ca}$ uptake stimulated by high $\mathrm{K}$ was blocked by CEBs (various DHPs, verapamil, diltazem), their potency reflecting the potencies in inhibiting K-induced contractions. However, ${ }^{45} \mathrm{Ca}$ uptake stimulated by angiotensin II and vasopressin was not blocked by these concentrations of CEBs. Therefore, the present results support the concept that POCs are more sensitive to CEBs than the ROCs (Cauvin et al., 1983; Godfraind et al., 1986).

However, the phasic component of the NAinduced contractions was unaffected suggesting that the release of $\mathrm{Ca}$ from intracellular stores is insensitive to oxodipine. To obtain further information on the effect of oxodipine on the NA-sensitive Ca store, the effects of oxodipine on NA-induced phasic contractions were studied. The phasic contractile response induced by NA in Ca-free media is similar to those found in rat (Ebeigbe \& Alaomaka, 1985) and rabbit aorta (Karaki et al., 1979) and has been attributed to mobilization of $\mathrm{Ca}$ from a membranebound store. In the present study oxodipine did not affect the amplitude of the NA-induced phasic contraction in Ca-free medium whether applied before or during 'Ca-loading'. This result suggests that oxodipine had no effect on the release of $\mathrm{Ca}$ from a membrane-bound store induced by NA and/or that the Ca store responsible for the phasic contraction is filled with extracellular $\mathrm{Ca}$ via an oxodipineinsensitive pathway. A similar explanation was proposed by Karaki et al. (1979) to explain why verapamil and D600 in concentrations of $10^{-6} \mathrm{M}$ did not affect this phasic response. Furthermore, at the maximum concentration tested which inhibited by almost $70 \%$ the NA-dependent ${ }^{45} \mathrm{Ca}$ uptake, oxodipine had no effect on ${ }^{45} \mathrm{Ca}$ efflux in resting, nonstimulated, as well as in aortic strips stimulated by NA. These results strongly suggest that at the concentrations at which it inhibits $\mathrm{Ca}$ entry, oxodipine fails to inhibit NA-induced intracellular $\mathrm{Ca}$ release. Similar results have been found in the presence of PY 108-068 (Hof et al., 1982) and nifedipine (Godfraind, 1983; Kanmura et al., 1983).

In conclusion, oxodipine is a new dihydropyridine derivative which like nifedipine inhibits $\mathrm{Ca}$ entry through voltage- and receptor-operated channels. However, oxodipine failed to inhibit $\mathrm{Ca}$ entry through passive leak channels and NA-induced intracellular $\mathrm{Ca}$ release.

We thank Dr A. Galiano, I.Q.B., S.A., for the generous gift of oxodipine and for helpful discussion. This work was supported by CAICYT and FISS Grant (2074/83).

\section{References}

BARRIGON, S., DELGADO, C., TEJERINA, T. \& TAMARGO, J. (1983). Effect of bunaphtine on ${ }^{45} \mathrm{Ca}$ movements in rat aortic smooth muscle. Experientia, 39, 761-763.

BARRIGÓN, S., TEJERINA, T., DELGADO, C. \& TAMARGO, J. (1984). Effects of chlorbutol on ${ }^{45} \mathrm{Ca}$ movements and contractile responses of rat aorta and its relevance to the action of Syntocinon. J. Pharmac. Pharmacol., 36, 521-526.

BOLTON, T. (1979). Mechanisms of action of transmitters and other substances on smooth muscle. Physiol. Rev., 59, 606-718.

CAUVIN, C., LOUTZENHISER, R. \& VAN BREEMEN, C. (1983). Mechanisms of calcium antagonist-induced vasodilation. Ann. Rev. Pharmacol. Toxicol., 23, 373396.

DETH, R. \& VAN BREEMEN, C. (1974). Relative contributions of $\mathrm{Ca}$ influx and cellular $\mathrm{Ca}$ release during drug induced activation of the rabbit aorta. Pflügers Arch., 348, 13-22.
EBEIBGE, A. \& ALOAMAKA, C. (1985). Mechanism of hydralazine-induced relaxation of arterial smooth muscle. Cardiovasc. Res., 19, 400-405.

EPSTEIN, S., ROSING, D. \& CONTI, R. (ed). (1985). Calciumchannel blockers: present status and future directions. Am. J. Cardiol., 55, 1B-220B.

FLECKENSTEIN, A. (1983). Calcium Antagonism In Heart and Smooth Muscle. Experimental Facts and Therapeutic Prospects. New York: John Wiley.

GODFRAIND, T. (1981). Mechanisms of action of calcium entry blockers. Fed. Proc., 40, 2866-2871.

GODFRAIND, T. (1983). Actions of nifedipine on Ca fluxes and contraction in isolated rat arteries. J. Pharmacol. Exp. Ther., 224, 443-450.

GODFRAIND, T. \& DIEU, D. (1981). The inhibition by flunarizine of the norepinephrine-evoked contraction and calcium influx in rat aorta and mesenteric arteries. $J$. Pharmacol. Exp. Ther., 217, 510-515.

GODFRAIND, T., HERMAN, A. \& WELLENS, D. (1984). 
Calcium Entry Blockers In Cardiovascular and Cerebral Dysfunctions. The Hague: Martinus Nijhoff Publishers.

GODFRAIND, T. \& KABA, A. (1969). Blockade or reversal of the contraction induced by calcium and adrenaline in depolarized arterial smooth muscle. Br. J. Pharmacol., 36, 548-560.

GODFRAIND, T., MILLER, R. \& WIBBO, M. (1986). Calcium antagonism and calcium entry blockade. Pharmacol. Rev., 38, 324-416.

GOLENHOFEN, K. \& LAMMEL, E. (1972). Selective suppression of some components of spontaneous activity in various types of smooth muscle by iproveratril (verapamil). Pflügers Arch., 331, 233-243.

GOLENHOFEN, K. \& HERMSTEIN, N. (1975). Differentiation of calcium activation mechanism in vascular smooth muscle by selective suppression with verapamil and D600. Blood Vessels, 12, 21-37.

HAEUSLER, G. (1972). Differential effects of verapamil on excitation-contraction coupling in smooth muscle and on excitation-contraction coupling in adrenergic nerve terminals. J. Pharmacol. Exp. Ther., 180, 672-682.

HUDGINS, P. \& WEISS, G. (1968). Differential effects of calcium removal upon vascular smooth muscle contraction induced by norepinephrine, histamine and potassium. J. Pharmacol. Exp. Ther., 159, 91-97.

KANMURA, T., ITOH, T., SUZUKI, H., ITO, Y. \& KURIYAMA, H. (1983). Effects of nifedipine on smooth muscle cells of the rabbit mesenteric artery. J. Pharmacol. Exp. Ther., 226, 238-248.

KARAKI, H., KUBOTA, H. \& URAKAWA, N. (1979). Mobilization of stored calcium for phasic contraction induced by norepinephrine in rabbit aorta. Eur. J. Pharmacol., 56, 237-245.
KAZDA, S., KNORR, A. \& TOWART, T. (1983). Common properties and differences between various calcium antagonists. Prog. Pharmacol., 5, 83-116.

MEISHERI, K., KWANG, O. \& VAN BREEMEN, C. (1981). Evidence for two separate $\mathrm{Ca}$ pathways in smooth muscle plasmalemma. J. Membr. Biol., 59, 19-25.

OPIE, L. (Ed.). (1984). Calcium antagonists and cardiovascular disease. In Perspectives in Cardiovascular Research. Vol. 9. New York: Raven Press.

RUEGG, U., WALLNOFER, A., CAUVIN, C. \& HOF, R. (1988). Potential sensitive and receptor operated calcium channels in vascular smooth muscle cells. J. Cardiovasc. Pharmacol. (abstract).

SCHUMMAN, H., GORLITZ, B. \& WAGNER, J. (1975). Influence of papaverine, D600 and nifedipine on the effects of noradrenaline and calcium on the isolated aorta and mesenteric artery of the rabbit. Naunyn-Schmiedebergs Arch. Pharmacol., 289, 409-418.

SIGURDSSON, S., UVELINS, B. \& JOHANSSON, B. (1975). Relative contribution of superficially bound and extracellular calcium to activation of contraction in isolated rat portal vein. Acta Physiol. Scand., 95, 263-269.

TEJERINA, T., DELGADO, C., VALENZUELA, C. \& TAMARGO, J. (1987). Comparative effects of oxodipine and nifedipine in the isolated guinea-pig heart. Arch. Int. Pharmacodyn., 288, 186-199.
(Received June 23, 1988

Revised January 16, 1989 Accepted January 27, 1989) 